НАУКОВИЙ ВІСНин

Sientific messenger of Lviv National University

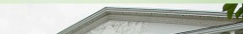

(1)

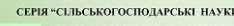

(3)) 22 № 93

2020
Науковий вісник Дьвівського національного університету ветеринарної медицини та біотехнологій імені С.3. Гжицького. Серія: Сільськогосподарські науки

Scientific Messenger of Lviv National University of Veterinary Medicine and Biotechnologies. Series: Agricultural sciences

https://nvlvet.com.ua/index.php/agriculture

UDC 636.32/38:591.16.612.063

\title{
Cryopreservation of ram-sires semen and its qualitative changes under the influence of low temperatures
}

\author{
K. Hrymak
}

Institute of Animal Biology NAAS, Lviv, Ukraine

Article info

Received 03.09.2020

Received in revised form 05.10 .2020

Accepted 06.10.2020

Institute of Animal Biology NAAS V. Stus Str., 38, Lviv,

79034, Ukraine.

Tel: +38-093-235-95-55

E-mail:phm89@ukr.net

Hrymak, K. (2020). Cryopreservation of ram-sires semen and its qualitative changes under the influence of low temperatures. Scientific Messenger of Lviv National University of Veterinary Medicine and Biotechnologies. Series: Agricultural sciences, 22(93), 102-112. doi: $10.32718 /$ nvlvet-a9318

The article presents in retrospect the methods of cryopreservation of sperm of bulls and breeding rams. It is indicated that the first methods were proposed by I.V. Smirnov in 1947-1951, which ensured the production of viable lambs and calves. The significant contribution to the development of the method of cryopreservation of bull sperm by British scientists Polge C. and Rawson L. and Japanese scientists Nagase H. and Niwa T. The methods developed by them, with minor changes, have been used by scientists and breeding specialists for many decades. Modern technologies of cryopreservation of bull sperm are represented, in particular: Kharkiv in coated granules (author FI Ostashko and others), French company IMV-R-Cassou, German company Minitub, which are currently used in most countries with developed animal husbandry. It is noted that the first attempts to freeze the sperm of breeding rams were made by E. M. Platov in 1965. It is noted that in the cryopreservation of sperm the importance of adaptation and equilibration processes is important. The role of glycerin as a cryoprotectant in freezing the semen of male farm animals has been elucidated. The optimal concentration of glycerin in the media for cryopreservation of sperm of fetuses has been established. It is noted that the basis of "temperature shock" of sperm is damage to the sperm membrane, which is caused by balancing the concentration gradient that occurs at the boundary of cell-medium division with a sharp change in temperature. A high correlation between the physiological quality of the acrosome of sperm and its fertilizing ability is indicated. Studies of the chemical composition of the sperm of breeding rams have shown that it differs from the sperm of other animal species by a slightly higher content of proteins, lipids of lactic acid and a lower concentration of minerals. Proteins contain much more amino acids. Sheep sperm do not tolerate aerobic conditions, it is proved that damage to sperm by oxygen occurs mainly after its dilution and equilibration, and not during cryopreservation. Under aerobic conditions, one amino acid is cleaved from the molecule of lecithin, which is part of the membranes of sperm, with the formation of toxic lysolecithin. The most critical zones at thawing of deep-frozen sperm are shown. It has been experimentally established that the rate of the recrystallization process can be reduced by using cryoprotectants in environments, as well as by increasing the rate of thawing. An important influence in the thawing of sperm has the selection of the optimal mode of thawing. Analysis of literature data revealed that in practical conditions in the process of freezing - thawing about $50 \%$ of sperm lose activity, which indicates that currently available methods of freezing sperm of breeding rams are imperfect and need further study and improvement. ability

Key words: breeding rams, semen, cryopreservation, thawing, equilibration, cryoprotectants, fertilizing

\section{Кріоконсервування сперми баранів-плідників та ії якісні зміни за дії низьких температур}

\author{
Х. М. Гримак \\ Інститут біології тварин НААН, м. Львів, Украӥна
}


У статті подано в ретроспективі методи кріоконсервування сперми бугаїв та баранів-плідників. Вказано, цчо перші методики були запропоновані I. В. Смирновим 1947-1951 роках, які забезпечили одержання життєздатних ягнят і телят. Підкреслено вагомий внесок у розробиі методу кріоконсервування сперми бугаїв англійських вчених Polge C. $i$ Rawson L. та японських вчених Nagase H. i Niwa T. Розроблені ними методи, із незначними змінами, застосовували науковці та спеціалісти племінної служби протягом багатьох десятків років. Репрезентовано сучасні технології кріоконсервування сперми бугаїв, зокрема: харківську в облицьованих гранулах (автор Ф. І. Осташко та інші), французьку фірми IMV-R-Cassou, німецьку фірми Міпітиь, які використовуються в даний час у більшості краӥн світу з розвинутим тваринництвом. Відмічено, щзо перші спроби заморожування сперми баранів-плідників здійснив Е. М. Платов у 1965 рочі. Зазначено, ичо при кріоконсервуванні сперми важливе значення належить прочесам адаптачії та еквілібрачії. 3 'ясована роль глічерину, як кріопротектора при заморожуванні сперми самиів сільськогосподарських тварин. Встановлена оптимальна концентрація гліцерину у середовищах для кріоконсервування сперми плідників. Відмічено, шео основою “температурного шоку” спермїв є пошкодження мембрани спермія, яке викликане внаслідок збалансування концентраційного градієнта, щуо виникає на межі поділу клітини-середовища за різкої зміни температури. Вказано на високу корелячію між фізіологічною якістю акросоми спермія і його запліднювальною здатністю. Дослідженнями хімічного складу сперми баранів-плідників встановлено, щуо вона відрізнясться від сперми інших видів тварин дещо вищим вмістом білків, ліпідів молочної кислоти і меншою концентрацією мінеральних речовин. До складу білків входить значно більше амінокислот. Спермії баранів погано переносять аеробні умови, доведено, шуо пошкодження сперми киснем відбувається переважно після ї̈ розбавлення і еквілібрачї̈, а не під час кріоконсервування. В аеробних умовах проходить відщеплення однієї амінокислоти із молекули лецитину, який входить до складу мембран спермїв, із утворенням токсичного лізолецитину. Показано найбільи критичні зони при розморожуванні глибокозамороженої сперми. Експериментально встановлено, щзо швидкість процесу рекристалізації можна зменшити шляхом застосування у середовищах кріопротекторів, а також підвищенням швидкості відтаювання. Важливий вплив при розморожуванні сперми має підбір оптимального режиму відтавання. Аналізом літературних даних виявлено, шчо у практичних умовах в процесі заморожування-розморожування близько 50 \% сперміїв втрачають активність, а цее свідчить, ццо наявні на даний час методи заморожування сперми баранів-плідників недосконалі і потребують подальшого вивчення та поліпшення.

Ключові слова: барани-плідники, сперма, кріоконсервування, розморожування, еквілібариія, кріопротектори, запліднювальна здатність.

\section{Вступ}

Результативність ведення галузі вівчарства значною мірою визначається ефективною селекційноплемінною роботою та широким застосуванням сучасних біотехнологічних методів відтворення, зокрема штучного осіменіння вівцематок деконсервованою спермою (Voronenko et al., 2009; Pokhyl et al., 2011; Mykytyn et al., 2013).

Ефективність методу штучного осіменіння тварин обумовлена можливістю зберігання сперми поза організмом самця і високих ступенів іiі розбавлення. У зв'язку 3 тим цей метод став основним важелем швидкого і масового покращення породного складу маточного поголів'я. Ще значно більші перспективи 3'явились у цьому аспекті з відкриттям у 1947-1949 роках I. В. Смирновим довготривалого зберігання сперми у глибокозамороженому стані (Smirnov, 1949). Автор розробив глюкозо-цитратно-жавткове середовище, в якому розбавляв сперму, поміщав іії у пакети 3 фольги по 0,05 мл і охолоджував до температури $79{ }^{\circ} \mathrm{C}$ або $196{ }^{\circ} \mathrm{C}$. Потім розморожував у водяній бані за температури $+38-40{ }^{\circ} \mathrm{C}$. За такої методики близько 15-30\% сперміїв зберігали прямолінійний поступальний рух. Після багаторазових осіменінь 18 піддослідних овець було одержано 12 нормальних життєздатних ягнят. У 1951 році були отримані перші телята від осіменіння корів деконсервованою спермою (Smirnov, 1951). Водночас англійські вчені C. H. Polge, L. E. A. Rowson (1952) запропонували методику повільного багатоступінчастого заморожування сперми у скляних ампулах, яка при частковій зміні режиму заморожування, середовища, адаптації і еквілібрації застосовувалась у багатьох країнах світу, понад десять років залишаючись в основному незмінною: двомоментне розбавлення сперми і триступінчастий режим заморожування.

Виробнича перевірка цього методу показала, що сперма після розморожування володіла задовільною активністю і запліднюючою здатністю. Цей метод мав важливий вплив на подальшу розробку і впровадження у виробництво низькотемпературного заморожування і зберігання сперми.

Однак застосовувана методика С. Н. Polge, L. E .A. Rowson (1952) для кріоконсервування сперми бугаїв виявилася непридатною для заморожування статевих клітин баранів. У дослідах I. White et el. (1954) після розморожування сперміїв баранів активність їх становила близько $50 \%$, а запліднювальна здатність лише 4,0 відсотка (Emmens \& Blackshow, 1955).

У дослідах А. И. Лонирина, Н. В. Логиновой (Lopyirin \& Loginova, 1958); В. А. Морозова (Morozov, 1957); М. П. Кузнецова, Л. П. Купрянова (Kuznetsov \& Kupriyanova, 1959) застосуваня гіпертонічних глюкозо-цитратно-жовткових середовищ 3 осмотичним тиском 8,8-12,5 атмосфери і вмістом гліцерину 7,5-8,0 \% та скороченням еквілібрації до 34 годин дещо покращувало активність деконсервованих спермії, проте запліднювальна здатність їх була низькою у межах 22 відсотка. Значно кращі результати за якістю деконсервованої сперми і запліднювальною здатністю були одержані при застосуванні для розбавлення сперми ізотонічних глюкозо-цитратних середовищ (Korotkov et al., 1960; Matskepladze et al., 1960).

H. Nagase, T. Niwa (1964) повідомили про новий розроблений ними метод заморожування сперми у гранулах. Свіжоодержану сперму бугаїв розбавляли лактозо-гліцерино-жовтковим середовищем у співвідношенні 1:1, 1:3 з таким розрахунком, щоб у об'ємі 0,1-0,2 мл була стандартна доза активних сперміїв. Еквілібрація сперми тривала 4-6 годин, після чого піддавалась швидкому заморожуванню на блоках сухого льоду протягом 10 хвилин. Швидкість охолодження каплі сперми становила $20-30{ }^{\circ} \mathrm{C}$ за хвилину. Створені у ямках сухого льоду гранули поміщали в сухий лід або рідкий азот. Розморожували гранули за 
температури $30-40{ }^{\circ} \mathrm{C}$ у $3 \%$ розчині лимоннокислого натрію. Цей метод мав декілька модифікацій і був широко поширений у багатьох країнах світу.

Н. П. Ющенко, В. Г. Семаков, К. А. Левин (1963) удосконалили вищевказаний метод, замінивши блок вуглекислоти фторопластовою пластиною, охолодженою рідким азотом, i впровадили його на племпідприємствах колишнього Радянського Союзу. Даний метод мав ряд переваг над раніше запропонованим. Заморожування сперми проходило значно швидше, а затрати часу i праці на технологічну обробку були меншими (Yuschenko et al., 1963).

Перші спроби заморожування сперми баранівплідників у гранулах здійснив Е. М. Платов (Platov, 1965). Для розбавлення автор використав ізотонічне лактозо-жовткове середовище 3 вмістом $3,5-4 \%$ гліцерину та еквілібрацією 3-4 години за температури $+2+4{ }^{\circ} \mathrm{C}$.

S. Salamon (1967), проводячи заморожування сперми баранів у глюкозо-цитратно-жовтковому середовищі в ампулах, гранулах і пайєтах, не виявив істотних відмінностей у якості деконсервованих сперміїв. Порівнюючи глюкозо-цитратно-жовткове і лактозожовткове середовище для заморожування сперми баранів із вмістом гліцерину відповідно 5 і $7 \%$ Г. Калев та ін. (1970) не виявили суттєвої різниці у якості деконсервованих сперміїв, їх активність становила $37-43 \%$, а запліднювальна здатність близько 24 відсотка.

Ф. І. Осташко, В. А. Шинкаренко (Ostashko \& Shinkarenko, 1972) інформували про нову технологію кріоконсервування сперми в облицьованих гранулах. Ії̈ застосування забезпечило підвищення заплідненості сперми, автоматизацію трудомістких процесів у лабораторіях племпідприємств, удосконалення оцінки сперми, мінімізацію дози сперми і її упаковки, практично вилучивши мікробний фактор при штучному осіменінні корів і телиць.

Дещо раніше у Франції фірмою Instrumens Medecine Veterinare (IMV), R-Cassou (1964) була розроблена і впроваджена у виробництво технологія заморожування сперми у пайєтах місткістю 0,5 мл. Для розбавлення сперми використовують середовище “Лецифос-271” або “Лецифос-470”. Заморожування проводиться протягом 9-10 хвилин у спеціальному штативі над поверхнею рідкого азоту. Швидкість заморожування сперми у пайєтах, (тонкостінних пластмасових капілярах) над поверхнею рідкого азоту приблизно така, як при заморожуванні гранул на фторопластових пластинах 20-30 ${ }^{\circ} \mathrm{C}$ за хвилину. Розморожують сперму зануренням соломинок у водяну баню за температури $+34^{\circ} \mathrm{C}$.

На основі цієї технології у Німечинні фірмою Minitub GmbH-Abfull-U. Labortechnik розроблена аналогічна технологія з використанням тонкостінних пайєт (соломинок) місткістю 0,25 мл. Технологічна лінія "Minitub" комплектується модулями IДА, Sperm Vision, Spart Dispenser і комбісистемною для розфасовки сперми у пайєти MPP Quattro з друкуючим принтером Leibinger Jet 2. Вказане обладнання технології виключає суб'єктивний фактор за оцінки нативної і деконсервованої сперми та автоматичне дозування розбавнивка. Застосування маркувальної машини надає можливість друкувати вичерпну інформацію про плідника і виробника на кожний пайєті - спермодози.

Для розбавлення еякуляту сперми використовують середовище “Андромед”, яке не містить білків тваринного походження, і його кріопротекторні властивості грунтуються на соєвому лецетині. До середовища також входять: фруктоза, трис, гліцерин і антибіотики. Розведення сперми проводять згідно 3 комп'ютерною програмою ІДА “Minitub”. Кінцева концентрація сперміїв у дозі 15 млн активних сперміїв. Після розбавлення сперму фасують у пайєти, ставлять у холодильну камеру на 2,5-4 години для еквілібрації, потім на програмному заморожувачі піддають кріоконсервуванню у парах азоту за температури $120{ }^{\circ} \mathrm{C}$ протягом 10 хв і переносять пайєти у рідкий азот для тривалого зберігання.

Проте застосування кріоконсервування сперми сучасними методами у практичних умовах підтверджує, що в процесі заморожування-розморожування близько $50 \%$ сперміїв втрачають активність, це свідчить про недосконалість розроблених і вживаних на даний час технологій.

Важливе значення при кріоконсервуванні сперми належить процесом адаптації і еквілібрації. Так, C. Polge, L. Rawson (Polge \& Rawson, 1952), Т. Ильинская (Ilinskaya, 1956), Х. Х. Хабибулин (Habibullin, 1958), J. C. A. Martin (Martin, 1963), Ф. І. Осташко, M. I. Лопатко (Ostashko \& Lopatko, 1965), А. Д. Бугров (Buhrov, 1965) та інші встановили, що витримування сперми протягом декількох годин за пониженої температури сприяє поліпшенню іiі якості після заморожування і визначили цей процес як призвичаювання сперміїв до низьких температур.

Цитоплазматична мембрана спермія є активним органоїдом, що забезпечує строго визначене дотримання у протоплазмі електролітнього складу, $\mathrm{pH}$, осмотичного тиску, тощо. Ф. І. Осташко (Ostashko, 1968), В. И. Канцедал (1969) зазначають, що в охолодженній спермі до $0{ }^{\circ} \mathrm{C}$ проходить перерозприділення концентрації іонів між середовищем і клітинною. Іони Натрію частково переміщуються 3 навколишнього середовища у клітину, а іони Калію - із клітини у плазму. На погляд авторів, таке переміщення іонів проходить у результаті припинення активної діяльності цитоплазматичної мембрани.

Отже, адаптація - перший етап переходу спермія в анабіотичне положення, що, безсумнівно, важливо у технології заморожування сперми. Не менш вагомим $\epsilon$ процес еквілібрації сперми, тобто урівноваженість концентрації кріопротекторів між середовищем і клітиною.

Відкриття американським вченим B. Luyet (Luyet 1937; Luyet \& Hodapp, 1938) явища вітрифікації за якої швидкість заморожування води досягає рівня $50000{ }^{\circ} \mathrm{C} / \mathrm{c}$, що у практичних умовах застосовувати неможливо, сприяло розробці методу глибокого заморожування сперми з використанням кріопротекторів, зокрема гліцерину.

Захисна дія гліцерину вперше була установлена Н. А. Максимовим (Maksimov, 1913; 1929) у середо- 
вищах при заморожуванні рослин. Застосування гліцерину при заморожуванні сперми сільськогосподарських тварин англійськими вченими С. Polge, A. Smith, A. Parvs (Polge et al., 1949), C. Polge, L. E. A. Rowson (Polge \& Rowson, 1952), C. Polge (Polge, 1953) забезпечило розробку методу кріоконсервування сперми савців.

Довготривалі та всебічні наукові дослідження зі кріоконсервування сперми тварин дали можливість I. В. Смирнову (Smirnov, 1974) висунути гіпотезу про одночасне протікання процесів кристалізації міжклітинної рідини і вітрифікації клітин. Згідно з цією теорією, за повільного охолодження сперми вільна вода поза і всередині клітини замерзає у виді кристалів і це призводить до загибелі сперміїв. При швидкому зануренні сперміїв у рідкий азот спермії теж гинуть, оскільки вода не встигає вийти із клітини, а для іiі вітрифікації потрібні недосяжні у практиці швидкості. Однак за охолодження 3 оптимальною швидкістю міжклітинна рідина кристалізується і утворює концентровані розчини солей і цукрів. Під дією концентрованих розчинів та осмотичного тиску із сперми виділяється вільна вода. Вода, що зв'язана 3 білками, значно відрізняється за властивостями від вільної, тому вітрифікується або утворюються дрібні кристали, які не пошкоджують клітину.

Е. М. Платов (1973) довів, що існує безпосередній зв'язок між швидкістю заморожування, формою кристалів і виживаністю сперміїв (Platov, 1973). На його погляд, вся внутрішньо- і позаклітинна вода в охолодженій і замороженій спермі перебуває у структурованому псевдокристалічному стані, що сприяє вітрифікації. Захисна дія гліцерину і цукрів пов'язана із структуризацією ними води і систематизацією структури. На думку Ф. І. Осташка (1968), механічне пошкодження сперміїв кристалами льоду малоймовірне через малі розміри сперміїв та еластичність їхніх мембран (Ostashko, 1968).

Гліцерин справляє специфічну осмотичну дію на спермії і на певний період створює осмотичний тиск, а після проникнення всередину спермія знову створює гіпотонію. За швидкого розбавлення сперми ізотонічними розчинами 3 вмістом гліцерину з'являється багато сперміїв 3 манежними рухами, скривлених, які рухаються вперед із зігнутою головкою (Smirnov, 1963; 1964; Ostashko \& Buhrov, 1966).

У початкових експериментах (Polge \& Rawson, 1952; Habibullin, 1957; Ostashko, 1959; 1960; Roslanovskiy, 1963; Pakenas 1963) сперму бугаїв розбавляли середовищами 3 кінцевою концентрацією гліцерину 7-10 \% з повільним наповненням ним сперми із піднашарованого середовища за температури + 4-5 $0{ }^{\circ} \mathrm{C}$ і еквілібрацією 18-24 години. Деякі автори рекомендували додавати гліцерин у середовище для заморожування сперми кількома порціями з інтервалом до 10 хвилин. Пізніше Ф. І. Осташко, М. І. Лопатко (Ostashko \& Lopatko, 1965) та інші встановили, що оптимальна кількість гліцерину у середовищах складає 5-8 відсотків. Вивчаючи осмотичну дію гліцерину на спермії бугая Е. М. Платов (Platov, 1960; 1963), H. Nagase (Nagase, 1964), О. Д. Бугров (Buhrov, 1965), Ф. І. Осташко, О. Д. Бугров (Ostashko \& Buhrov, 1966) розробили методику одномонентного розбавлення сперми гліцеринізованими середовищами за кімнатної температури.

А. С. Яцун, Т. Н. Ільїнская (Yatsun, \& Ilinskaya, 1969), А. С. Волков (Volkov, 1971) повідомили, що гліцерин із середовища сперми за температури, близької до $0{ }^{\circ} \mathrm{C}$, а також у процесі заморожування не проникає через оболонку у спермії. Дослідники припускали, що кріозахисний його вплив проявляється у взаємодії зі складниками середовища у змінюванні його фізико-хімічних властивостей. W. E. Berndtson, R. H. Foote (Berndtson \& Foote, 1972) B. А. Наук, Г. Е. Дарий (Nauk, 1974) теж вважали, що для кріозахисту сперміїв не обов'язкове проникнення гліцерину всередину, достатньо екстрацелюлярної кріопротекціï. Проте проведенні дослідження (Kushnir, 1974; Zvereva, 1976) свідчать про швидке проникнення гліцерину у спермії, що суперечить раніше одержаним результатам досліджень вчених про повільне його проникнення.

Для еквілібрації сперми необхідний відповідний період часу. У процесі вивчення еквілібраційного періоду були запропоновані різні його терміни. Так, C. Polge, L. E. A. Rowson (Polge \& Rawson, 1952), Т. П. Ильинская (Ilinskaya, 1963), П. И. Пакенас (Pakenas, 1963), О. Д. Бугров (Bugrov, 1965) рекомендували насичувати сперму гліцерином 16-24 години. Однак, ряд авторів повідомили про успішне заморожування сперми бугаїв протягом значно коротшого еквілібраційного періоду - до 4 годин W. J. Odell, I. O. Almquist (1954, 1957), до 2 годин (Miller \& VanDemark, 1954) і до 30 хвилин (Emmens \& Blackshow, 1955; Wiggin \& Almquist, 1975).

В. А. Наук, Г. Е. Дарій (Nauk, 1974), А. П. Зверєва (Zvereva, 1976; 1977), R. Jodent (Jodent, 1979) пропонували вводити гліцерин безпосередньо перед заморожуванням. За даними А. П. Зверєвої, скорочення терміну гліцеринізації до 2-3 хвилин поліпшує якість деконсервованої сперми, збільшує іiі виживаність, підвищує активність і запліднювальну здатність. На іiі думку поліпшення якості сперми після короткотермінованої гліцеринізації пояснюється дегідративною дією гліцерину, його властивістю швидко проникати у спермії бугая.

Електронно-мікроскопічними дослідженнями (Zvereva \& Chernomaz, 1963; Blom, 1964; Petruk, 1966; Varnavskiy, 1969; 1970; Milovanov et al., 1970; Skornyakov, 1973), встановлено, що гліцеринізація, особливо довготривала, $є$ однією 3 причин пошкодження сперміїв. Автори вказують на руйнування оболонки спермія, насамперед в ділянці головки, шийки і кінцевої ділянки хвоста, де оголюються фібрили. Згідно з даними Б. А. Скорнякова, у процесі гліцеринізації проходить збільшення до 48 \% кількості пошкоджених сперміїв.

Отже, перебування сперміїв у гліцеринізованому середовищі, навіть при температурах близьких до $0{ }^{\circ} \mathrm{C}$, коли обмінні процеси значно уповільненні, негативно впливає на їх життєздатність.

Е. М. Платов (Platov, 1965) у склад середовища для кріоконсервування сперми баранів вводив етиленгліколь. За повільного заморожування сперми етиленглі- 
коль не володів превентивною властивістю, а при швидкому заморожуванні спостерігалася висока активність та виживаність сперміїв, як у середовищі із гліцерином. Проте запліднювальна здатність сперміїв була невисокою.

Досліджуючи захисну дію різних кріопротекторів у середовищах для заморожування сперми баранів, S. Salamon (1968) експериментально підтвердив, що гліцерин краще оберігає сперміїв при кріоконсервуванні, ніж етиленгліколь чи комбінація етиленгліколю 3 диметилсульфоксидом. R. G. Jones (1965) повідомив, що введення у середовище для розбавлення сперми баранів $5 \%$ розчину диметилсульфоксиду різко знизило якісні показники деконсервованої сперми.

Найоб'єктивніше відображає процеси, що протікають у спермі при ії охолодженні, шкала, запропонована Ф. І. Осташком (Ostashko, 1968). Він розділив температурний діапазон на такі зони: від +40 до $+25{ }^{\circ} \mathrm{C}$ - зона високої активності обмінних процесів; від +25 до $-5{ }^{\circ} \mathrm{C}-$ зона пониженого рівня обмінних процесів і перехід клітин у стан мезабіозу; від -0,5 до $80{ }^{\circ} \mathrm{C}$ - зона кристалізації охолодженої та переохолодженої навколишньої і внутрішньоклітинної води та перехід клітин у стан анабіозу; від -80 до $-150{ }^{\circ} \mathrm{C}-$ зона кристалізації в'язкої і адсорбованої води та рекристалізаційних процесів; від -150 до $-273{ }^{\circ} \mathrm{C}-$ зона відсутності кристалізаційних процесів (зона квантових реакцій).

Значну небезпеку для сперміїв становляють осмотичні явища, що виникають на мебрані в результаті швидкого охолодження чи розмороження клітин. Ці явища одержали назву “температурний шок”, їх спостерігали при різкому охолодженні сперми баранів, бугаїв, хряків В. К. Милованов (Milovanov, 1962), Ф. I. Осташко (Ostashko, 1964) та інші. Ф. І. Осташко (Ostashko, 1964; 1968) експериментально довів, що основою температурного шоку є пошкодження мембрани спермія, яке викликане збалансуванням концентраційного градієнта, що виникає на межі поділу клітини - середовища за різкої зміни температури. Враховуючи те, що клітина оточена мембраною, яка володіє вибірковою проникненістю, урівноваженість проходить внаслідок поступлення і виходу води із клітини. Надзвичайно швидкий потік води через мембрану може їі пошкодити.

Репрезентована Р. Mazur (1977) гіпотеза про кінетику зневоднення клітин при заморожуванні стала основою двохфакторної теорії пошкодження біологічних об'єктів. Згідно з цією теорією, на першому етапі від 0 до $7^{\circ} \mathrm{C}$ найбільш негативно діє чинник, який сприяє швидкій дегідрації клітин, а на другому етапі від -7 до $-50{ }^{\circ} \mathrm{C}$ найбільшу небезпеку викликає підвищення концентрації солей.

Аналіз методів кріоконсервування сперми плідників сільськогосподарських тварин указує, що на виробництві застосовують двоетапні режими заморожування. При кріоконсервуванні сперми у гранулах температура від 0 до $-10{ }^{\circ} \mathrm{C}$ знижується повільно, а потім на відрізку від -11 до $-196{ }^{\circ} \mathrm{C}$ дуже швидко. Повільне заморожування на першому етапі спричиняє позаклітинну кристалізацію і спермії, що містяться у концентрованих розчинах, зневоднюються. Дегідра- тація сприяє вітрифікації води всередині клітин, а також утворенню дрібних кристалів, які не пошкоджують сперміїв (Ostashko, 1968; Smirnov, 1974).

Багатьма дослідниками (Martin, 1963; Pursel et al., 1972; Watson, 1975; Wilmut \& Polge, 1977; Korban et al., 1980; Kononov, 1983) доведено, що при швидкому охолодженні сперми бугаїв, баранів і кнурів від $37^{\circ}$ до $0{ }^{\circ} \mathrm{C}$ спермії втрачають рухливість і метаболічну активність, яка супроводжується виходом із сперміїв у плазму внутрішньоклітинних ферментів, білків, а також перерозподіленням іонів між статевими клітинами і навколишнім середовищем. Водночас спостерігається перелом сперміїв у ділянці шийки, скручування джгутика та пошкодження акросом. Автори зазначають, що обсяг пошкодження сперміїв бугаїв, баранів і кнурів різний. У бугаїв кількість сперміїв 3 пошкодженою акросамою після холодового шоку становила $28 \%$, баранів - 49 і кнурів - 78 відсотків.

За результатами досліджень (Schmidt et al., 1974; Zheltobryuh \& Ivahnenko, 1977; Zheltobryuh \& Ivahnenko, 1977; Sokolovskaya et al., 1981) існує висока кореляція між фізіологічною якістю акросоми спермія і його запліднювальною здатністю.

Автори вважають, що оцінка стану акросоми деконсервованих сперміїв $\epsilon$ достовірнішою за їхню біологічну повноцінність, ніж визначення активності та виживаності. Було запропоновано декілька способів визначення пошкоджень акросами сперміїв, а саме: фарбування мазків сперми спеціальними фарбами; визначення протеолітичної активності (ПЛА) акросом; акроскопічний метод, який грунтується на зміні заломлення світла при баковому освітленні розбавленої краплі сперми за допомогою конденсора темного поля (Watson, 1975; Rhodes, 1980; Harrison \& Flechon, 1980; Marinov, 1981; Sokolovskaya et al., 1981).

Вивченням ультраструктурних пошкоджень сперміїв у процесі кріоконсервування з'ясовано, що частка сперміїв з пошкодженими акросами збільшується по шляху проходження технологічних етапів кріоконсервування. За даними (Fornusek et al., 1981), відсоток сперміїв з ушкодженою акросомою у свіжоодержаній спермі баранів складає $16 \%$, а в деконсервованій 44-59 відсотків. Більшість пошкоджень акросоми, на переконання авторів, відбувається під час розбавлення і еквілібрації і значно менше - в процесі самого заморожування.

Дослідженнями (Aybazova, 1987) встановлено, що тільки 15-36 \% деконсервованих сперміїв баранівплідників не мали структурних пошкоджень акросоми i цитоплазматичної оболонки. Автор зазначає, що етапи (стадії) підготовки сперми до кріоконсервування, а саме: розбавлення середовищем та еквілібрація також впливають на активність, виживаність та біологічну повноцінність.

T. Mann (Mann, 1964), Е. М. Платов (Platov, 1973), Л. Г. Мороз та ін. (Moroz et al., 1976) виявили, що активність сперміїв та їх виживаність після холодового шоку поєднана зі зменшенням вмісту аденозинтрифосфатази (АТФ) внаслідок зниження інтенсивності гліколізу і дихання. Проте на стадії охолодження сперми до 5-0 ${ }^{\circ} \mathrm{C}$ зменшення вмісту АТФ не 
пов'язано $з$ порушенням його синтезу, тому після розмороження сперми вміст АТФ відновлюється.

Виявлено, що при розбавленні, еквілібрації, кріоконсервуванні та розморожуванні сперми руйнується проникність мембран, яка призводить до витікання зі сперміїв ряду ферментів і збільшення їхньої активності у плазмі, а також утратою основних компонентів мембран - ліпідів та білків (Shergin, 1967; Nauk, 1974; Kurilo, 1982; Semekov, 1984).

Стійкість мембран сперміїв до холодового шоку також залежить від вмісту в них холестерину та співвідношення насичених і ненасичених жирних кислот у фосфоліпідах. Установлено, що оболонка сперміїв баранів містить незначну кількість міцно зв'язаних холестероло-протеїдних комплексів, які забезпечують стійкість статевих клітин до низьких температур, оскільки крихко зв'язані комплекси більш гідрофільні і швидше руйнуються за кріоконсервування.

Вміст поліненасичених жирних кислот і холестерину, згідно з теорією фазового переходу ліпідів, визначають температуру фазового переходу ліпідів із рідкокристалічного стану до кристалічного. Холестерин, взаємодіючи із жирнокислотними кільцями, знижує текучість мембран. Причому - чим нижча температура фазового переходу, тим більша стійкість мембрани. Також доведено, що після кріоконсервування і відтавання сперміїв у них зменшується вміст амінокислот в основному за рахунок гідрофобних і нейтральних в середньому на 15-31\%. Співвідношення білка до ліпідів у мембранах, на думку деяких дослідників, характеризує видову специфічну стійкість сперміїв до заморожування. У спермі бугаїв це співвідношення дорівнює 0,43, а у спермі баранів - 0,36 (Watson, 1981; Belous et al., 1982; Nauk, 1982).

P. Watson (Watson, 1975), M. Mollova, (Mollova, 1980), Д. Т. Данов та ін. (Danov et al., 1984) експериментально довели, що однією 3 основних причин зниження запліднювальної здатності сперміїв під час кріоконсервування, поряд 3 пошкодженням зовнішньої цитоплазматичної оболонки спермія і руйнуванням акросами, є значні втрати амінокислот, ліпопротеїдів і пошкодження ферментних систем.

Порушення ферментних систем сперміїв, а також втрата властивостей їх до ресинтезу аденозинполіфосфатів (АТФ і АДФ) призводить до зміни енергетики сперміїв та зниження виживаності у репродуктивних органах овець. Встановлено, що у процесі кріоконсервування сперми баранів спостерігається втрата значної кількості амінокислот, що входять до складу ліпоглюкопротеїдних комплексів акросоми і цитоплазми. Причому втрати амінокислот у сперміях баранів майже у два рази більші, ніж у бугаїв, відповідно 20,0 і 11,0 відсотка (Aybazova, 1987).

Не менш важливе значення надається процесу розморожування глибокозамороженої сперми, оскільки на стадії рекристалізації у зв'язку з підвищенням навантаження на мембрану спермія спостерігається їх пошкодження. Найбільш критичні зони при розморожуванні сперми перебувають у діапазоні температур від -50 до $-30{ }^{\circ} \mathrm{C}$, а також від -30 до $0{ }^{\circ} \mathrm{C}$. Експериментально встановлено, що швидкість процесу рекристалізації можна зменшити шляхом застосування у сере- довищах кріопротекторів, а також підвищенням швидкості відтаювання. Вагомий вплив при розморожуванні сперми має підбір оптимального режиму відтавання (Bugrov \& Olekseenko, 1977).

Заморожування і розморожування сперми викликає значне відшаровування і набрякання мембран, їх розриви як плазматичних, так i акросомальних. У зв'язку 3 тим помітні зміни акросоми. Одночасно відбувається розбухання мітохондріальної спіралі спермія, просвітління матриці мітохондрій, руйнування окремих мітохондріальних тіл. Виявлено, що у сперміях баранів найбільше, порівняно із сперміями бугаїв, пошкоджується плазматична мембрана і акросама. Це свідчить про основну причину невисокої запліднювальної здатності деконсервованої сперми баранів (Varnavskiy, 1970; Schmidt et al., 1974).

Проведеними Н. П. Шергіним (1967) дослідженнями хімічного складу сперми баранів-плідників встановлено, що вона відрізняється від сперми інших видів тварин дещо вищим вмістом білків, ліпідів, молочної кислоти і меншою концентрацією мінеральних речовин. До складу білків входить значно більше амінокислот. Зокрема: аргінін - 20,9 \%, лейцин і ізолейцин - 13,8 \%, глютамінова кислота - 6,2 \%, треонін $-3,1 \%$, лізин - 9,6 \%, гістидин - 4,8, тирозин $9,4 \%$, фенілаланін - 10,4\%, серин - 3,6 \%, гліцин $2,8 \%$, аспаргінова кислота - 2,6 \%, валін - 6,2 \%, аланін - 3,0 \%, метіонін - 2,0 відсотка.

У сперміях містяться такі ферменти, як сукцинатдегідрогенеза, цитохромоксидаза, гіалуронідаза, лужна і кисла фосфатази та інші. У плазмі сперми баранів порівняно з іншими видами самців міститься більше цукрів, в основному моносахаридів-фруктози, галактози, глюкози, арабінози, рибози, рибулези. Із органічних кислот перевагу має лимонна, а 3 мінеральних солей - хлорид натрію.

Вивченням морфологічних біохімічних показників були виявлені основні специфічні особливості сперміїв баранів за їх кріоконсервуванням. Спермії баранів погано переносять аеробні умови. У каудальній частині придатка сім'яника вони перебувають в анаеробних умовах. Дослідженнями доведено, що пошкодження сперми киснем відбувається основними чином після іiї розбавлення і еквілібрації, а не під час кріоконсервування. Встановлено, що в аеробних умовах проходить відщеплення однієї амінокислоти із молекули лецитину, який входить до складу мембран сперміїв з утворенням токсичного лізолецитину.

Враховуючи надзвичайно важливе значення акросоми при заплідненні яйцеклітини, можна пояснити різницю між високою активністю деконсервованих сперміїв та їх запліднювальною здатністю (Varnavskiy, 1970; Zhiltsov, 1970; Milovanov, 1975; Milovanov et al., 1976; Zhiltsov, 1999).

Рядом вчених, зокрема М. П. Кузнецовим (Kuznetsov \& Kupriyanova, 1959), Н. 3. Жильцовим та ін. (Zhiltsov et al., 1974), П. Івановим, В. Димовим (1974) було встановлено, що у спермі баранів порівняно із спермою бугаїв є значна кількість простагландинів: ПГЕ 50 мкг/мл і ПГФ - 12 мкг/мл. Вони стимулюють мускулатуру матки і сприяють руху сперміїв до місця запліднення. Проте за своєю природою вони 
$€$ ненасиченими жирними кислотами і при аеробній підготовці до кріоконсервування інактивуються і це знижує ефективність осіменіння овець аеробнозамороженою спермою. Доведено, що у спермі баранів, підготовленою до кріоконсервування за технологією бугаїв, фактично проходить повна інактивація сперміїв, замість 62 мкг/мл залишається лише 1,3 мкт/мл. Водночас додавання простагландинів до деконсервованої сперми при осіменінні овець забезпечує збільшення у два рази кітних вівцематок.

Також виявлено, що у спермі баранів порівняно зі спермою інших сільськогосподарських тварин відсутній природній антиоксидант. Внаслідок перекисного окиснення руйнується акросома, яка містить необхідні для запліднення ферменти - акрозин і гіалуронідазу. Тому негативну дію кисню на спермії баранівплідників можна відвернути анаеробною атмосферою при підготовці до заморожування халатними агентами, які зв'язують іони тяжких металів та антиоксидантами (Milovanov \& Sokolovskaya, 1980).

R. H. Hammarstedt et al. (Hammarstedt et al., 1976), И. Н. Шайдулин (Shaydullin, 1980) вважають, що певні антиоксиданти можуть оберігати спермії від холодового шоку, аналогічно жовтку. Однак до складу середовища для розбавлення і подальшого кріоконсервування сперми обов'язково все ж таки вводити 1520 відсотка жовтка, що вказує на недостатнє вивчення впливу антиоксидантів.

I. М. Кушнір (Kushnir, 1998) зазначає, що якість деконсервованої сперми залежить від протікання дифузно-осмотичних процесів між сперміями і середовищем із кріопротектором. Тому обов'язково потрібно враховувати осмолярну концентрацію сперми, середовища і кожного компонента у ньому.

\section{Висновки}

Iз аналізу літературних даних видно, що видові зміни стійкості сперміїв баранів до охолодження i кріоконсервування обумовлені особливостями хімічного складу плазми, молекулярної організації мембран сперміїв, ферментного набору і метаболізму. Все це потрібно враховувати при удосконаленні технології заморожування сперми баранів-плідників, у тому числі й засобів захисту в період підготовки ії до кріоконсервування, оскільки існуючі методи заморожування сперми недосконалі й потребують подальшого вивчення та поліпшення.

\section{References}

Aybazova, M. M. (1987). Usovershenstvovanie tehnologii kriokonservatsii spermyi i ispolzovanie tsennyih baranov-proizvoditeley. Avtoreferat diss. kand. vet. nauk. Stavropol. SSHI (in Russian).

Aybazov, M. M. (2004). Biotehnologiya vosproizvodstva ovets i koz: monografiya (in Russian).

Belous, A. M., Bondarenko, V. A., \& Shrago, M. G. (1982). Strukturnyie izmeneniya biologicheskih membran pri ohlazhdenii. Nauk. dumka (in Russian).

Berndtson, W. E., \& Foote, R. H. (1972). The freezability of spermatozoa after minimal pre-freezing exposure to glycerol or lactose. Cryobiology, 9(1), 57-60. doi: 10.1016/0011-2240(72)90010-7.

Blom, E. (1964). The galea capitis as pert of the acrosome in the bull sperm. Animal Reprod. Trento, 4, 655-666.

Blom, E. (1964). Spermatic ultrastructure (bovine). Spermatic ultrastructure (bovine). 3. Edition springfield, Nass, 425-430.

Bugrov, A. D., \& Olekseenko, T. N. (1977). Kriticheskie zonyi ottaivaniya spermyi byikov $\mathrm{i}$ ih vliyanie na vyizhivaemost spermiev. Selskohozyaystvennaya biologiya, 13(3), 368-370 (in Russian).

Buhrov, O. D. (1965). Vplyv osmatychnoho tysku na simia plidnykiv pry yoho hlybokomu zamorozhuvanni. Zb. Rozvedennia i utrymannia silskohospodarskykh tvaryn, 5, 36-41 (in Ukrainian).

Cassou, R. (1964). La méthode des paillettes en plastique adaptée a la généralisation de la congélation. In Fifth International Congress on Animal Reproduction and Artificial Insemination (Trento), 4, 540-546.

Danov, T. D., Kovachev, K. D., \& Kresteva, S. H. (1984). Nakoi formi na uvrezhdane i otklonenie ot normalnata Ultrastruktura na spermatozoidite na kocha. Biol. Et immunal. Reprod, 9, 87-94.

Davidenko, V. M., Shinkarenko, I. S., \& Ignatenko, O. I. (1977). Vliyaniya nekotoryih faktorov na kachestvo spermyi pri zamorazhivanie. Nauchno-tehn. Byull. Ukr. NIIZh shtatnyih rayonov "Akanya Nova", 41, 60-63 (in Russian).

Emmens, C. W., \& Blackshow, A. W. (1955). The fertility of frozen ram and bull semen. Austral. Veter. I, 31(3), 76-79. doi: 10.1111/j.1751-0813.1955.tb05502.x.

Fornusek, L., Vetvickova, V., \& Petelikova, I. (1981). Usinek redidel pro dlouhodobe uchovavani na akrosomy beranich spermii. Veter.-Med. (CSSR), 26, 213-221.

Habibullin, H. H. (1957). Sohranenie i perevozka spermyi byikov pri nizkih temperaturah. Molochnoe i myasnoe zhivotnovodstvo, 5, 39-42 (in Russian).

Habibullin, H. H. (1958). Hranenie semeni byika v zamorozhennom sostoyanii. Molochnoe yi myasnoe zhivotnovodstvo, 2, 43-47 (in Russian).

Hammarstedt, R. H., Amman, R. P., \& Ruinsky, T. (1976). Biol. Reproductions, 14, 381-387.

Harrison, R. A. P., \& Flechon, J. E. (1980). Immunocytochemical detection of acrosomal damage following cold shock: loss of acrosin from the acrosomal region of ram, bull and boar spermatozoa. Reproduction Nutrition Développement, 20(6), 1801-1810. doi: 10.1051/rnd:19801006.

Ilinskaya, T. P. (1963). O rezultatah zamorazhivaniya semeni byikov $\mathrm{v}$ Belorussii. $\mathrm{V} \mathrm{kn}$. Novoe $\mathrm{v}$ plemennom dele $\mathrm{v}$ iskusstvennom osemenenii selskohozyaystvennyih zhivotnyih, 389-394 (in Russian).

Jodent, R. (1976). Recent technological progress in artificial insemination of cows. Italian. Selezione Veterinaria.

Jones, R. W. (1965). The use dimethyl sulfoxide glycerol and reconstituted skim milk for preservation of ram spermatozoa. Austral. J. Biol.Sci., 18(4), 877-885. doi: 10.1071/BI9650877. 
Kalev, G., Zagorskiy, D., Bapirdzhiev, K. i dr (1970). Osemenenie ovets glubokozamorozhennoy spermoy, razbavlennoy razlichnyimi sredami. Zhivotnovodstvo, 7, 28-31 (in Russian).

Kantsedal, V. I. (1968). Nekotoryie voprosyi fiziologii i biohimii spermyi hryakov i baranov. Avt. dis.. kand. biol. nauk. Kazan (in Russian).

Kononov, V. P. (1983). Dostizheniya i perspektivyi zamorazhivaniya semeni $\mathrm{v}$ svinovodstve. M.: Rosselhozizdat (in Russian).

Korban, N. V., Moroz, L. G., \& Shapiev, I. Sh. (1980). Metodicheskie rekomendatsii po nizkotemperaturnoy konservatsii spermyi hryakov (in Russian).

Korotkov, A. I., Marchenko, M., \& Moskalyuk, M. (1960). Hranenie semeni baranov pri temperature $-78^{\circ}$ C. Zemledelie i zhivotnovodstvo Moldavii, 1, 42-44 (in Russian).

Kurilo, Yu. G. (1982). Vzaimosvyaz aktivnosti fermentov i kontsentratsii metabolitov uglevodnogo obmena $\mathrm{v}$ sperme hryakov s kachestvom spermyi, perezhivaemostyu i oplodotvoryayuschey sposobnosti spermiev (Doctoral dissertation, stupenya dok. biol. nauk: spets. 03.0013 "fiziologiya". Harkiv (in Russian).

Kushnir, V. M. (1974). Deystvie osmoticheskih faktorov pri zamorazhivanii spermyi byikov $\mathrm{V}$ sredah $\mathrm{s}$ glitserinom Avtoreferat kand. diss (in Russian).

Kushnir, V. M. (1998). Perspektivyi razvitiya teorii i praktiki kriokonservatsii spermyi. Konkurentosposobnoe proizvodstvo produktsii zhivotnovodstva $\mathrm{v}$ Respublike Belarus: Sb. rabot Mezhd.nauch, 146-148 (in Russian).

Kuznetsov, M. P., \& Kupriyanova, L. P. (1959). K voprosu sohraneniya semeni baranov pri temperature $79^{\circ} \mathrm{C}$. Tr. Vizha, 23, 171-190 (in Russian).

Kuznetsov, L. N. (1990). Opyit glubokogo ohlazhdeniya i dlitelnogo hraneniya semeni baranov. Novoe $v$ plemennom dele $\mathrm{i}$ iskusstvennom osemenenii selskohozyaystvennyih zhivotnyih (in Russian).

Lopyirin, A. I., Loginova N. V. (1958). Metodike zamorazhivaniya semeni barana. Ovtsevodstvo, 8, 3134 (in Russian).

Luyet, B. J. (1937). The vitrification of organic colloids and of protoplasme. Biodynamica.

Luyet, B. J., \& Hodapp, E. L. (1938). Revival of frog's spermatozoa vitrified in liquid air. Proceedings of the Society for Experimental Biology and Medicine, 39(3), 433-434. doi: 10.3181/00379727-39-10229P.

Maksimov, N. A. (1913). O vyimerzanii vodyi i holodostoykosti rasteniy (in Russian).

Maksimov, N. A. (1929). Vnutrennie faktoryi ustoychivosti rasteniy $\mathrm{k}$ morozu i zasuhe. Trudyi po prikladnoy botanike, genetike i selektsii, 22(1), 3-41 (in Russian).

Mann, T. (1964). Biochemistry of semen of the male reproduct. Tract. Science, 147, 3659, 727-728. doi: 10.1126/science.147.3659.727-a.

Marinov, P. (1981). La accion proteoritika del acrosome como metodo de valoracion del efecto crioprotector de dillnyentes para la congelacion de semen ovino. Biol. Immunal. Reproduct, 5, 44-48.
Martin, J. C. A. (1963). The influence of diluente and processin time ofter ejaculation on the revival of deep frozen bull spermatozoa. J. Agric. Sei, 63, 55-63.

Martin, I. C. A. (1963). Effects of lecithin, egg-yolk, fructose and period of storage at $5^{\circ} \mathrm{c}$ on bull spermatozoa deep-frozen to-79 $\mathrm{C}$. Reproduction, 6(3), 441-449. doi: 10.1530/jrf.0.0060441.

Matskepladze, I. B., Gugushvili, K. F., Bregadze, M. A i dr (1960). Sohranenie i ispolzovanie semeni byika i barana v zamorozhennom sostoyanii. Zhivotnovodstvo, 2, 7779 (in Russian).

Mazur, P. (1966). Theoretical and experimental effects of cooling and warming velocity on the survival of frozen and thawed cells. Cryobiology, 2(4), 181-192. doi: 10.1016/S0011-2240(66)80165-7.

Mesanos, P., Wamsik, R., \& Schavac, F. (1977). Prezivatel spermii barana pri pouziti roznych bruhov riedidiel pohlbokom zmrazeni v tekutom dusuku. Vet. Med, 22, 599-604 (in Russian).

Miller, W. J., \& VanDemark, N. L. (1954). The influence of glycerol level, various temperature aspects and certain other factors on the survival of bull spermatozoa at sub-zero temperatures. Journal of Dairy Science, 37(1), 45-51. doi: 10.3168/jds.S00220302(54)91230-8.

Milovanov, V. K. (1962). Biologiya vosproizvedeniya i iskusstvennoe osemenenie zhivotnyih. Kolos (in Russian).

Milovanov V. K. (1975). Eksperiment k bionike epididimisa ( $\mathrm{k}$ tehnologii hraneniya semeni selskohozyaystvennyih zhivotnyih). Dokladyi VASHNIL, 10, 26-28 (in Russian).

Milovanov, V. K., \& Sokolovskaya, I. I. (1980). Dlitelnoe hranenie semeni barana i novyie vozmozhnosti krupnomasshtabnoy selektsii v ovtsevodstve. Vestnik selskohozyaystvennoy nauki, 2, 122-131 (in Russian).

Milovanov, V. K., \& Sokolovskaya, I. I. (1980). Uroven i perspektivyi nauchnyih issledovaniy. Zhivotnovodstvo, 10, 48-50 (in Russian).

Milovanov, V. K., Varnavskiy, A. N., \& Nauk, V. A. (1970). O prirode kriogennyih povrezhdeniy zhivchikov barana. Vestnik s-h nauki, 10, 86 (in Russian).

Milovanov, V. K., Varnavskiy, A. N., \& Varnavskaya, V. A. (1976). Razrabotka metoda glubokogo zamorazhivaniya semeni baranov dlya dlitelnogo hraneniya. Zhivotnovodstvo, 8, 57 (in Russian).

Mollova, M. V. (1980). Changes in the structure of ram spermatozoa after equilibration and deep freezing. In Doklady Bolgarskoi Akademii Nauk, 33(3), 393-395.

Moroz, L. G., Shapiev, I. Sh., Korban, N. V., \& Mashanskiy, V. F. (1976). Fiziologicheskie i biohimicheskie izmeneniya spermatozoidov hryaka pri zamorazhivanii. Selskohozyaystvennaya biologiya, 11(6), 850-856 (in Russian).

Morozov, V. A. (1957). Sohranenie semeni barana v zamorozhennom sostoyanii posredstvom gipertonicheskih rastvorov. Dokladyi VASHNII, 11, 44-48 (in Russian).

Mykytyn, L. Ye., Binkevych, V. Ya., \& Bilyk, O. Ya. (2013). Stan ta perspektyvy rozvytku vivcharstva v Ukraini. Naukovyi visnyk Lvivskoho natsionalnoho 
universytetu veterynarnoi medytsyny ta biotekhnolohii im. Gzhytskoho, 15, 1(4), 133-141 (in Ukrainian).

Nagase, H. (1964). Deep-freezing bull semen in concentrated pellet form. I. Factors affecting survival of spermatozoa. In Proceedings of the 4th International Congress on Animal Reproduction and Artificial Insemination, 3, 410-415.

Nauk, V. A. (1973). Sohraneniya semeni barana i izmenenie soderzhanie aminokislot pri nizkih temperaturah. Razvedenie i kormlenie selskohozyaystvennyih zhivotnyih, 111-113 (in Russian).

Nauk, V. A. (1974). Izmeneniya pronitsaemosti membran i ustoychivosti belkovo-holosterinovyih kompleksov zhivchikov pod vliyaniem tehnologicheskiy obrabotki semeni byika. Selskohozyaystvennaya biologiya, 9(1), 102-108 (in Russian).

Nauk, V. A. (1974). O tselesoobraznosti otkaza ot "ekvilibratsii" pri zamorazhivanii semeni byikov. Zhivotnovodstvo, 10, 71-74 (in Russian).

Nauk, V. A. (1982). Kriokonservatsiya semeni zhivotnyih. Pushkino: Institut biologicheskoy fiziki (in Russian).

O’dell, W. T., \& Almquist, J. O. (1957). Freezing bovine semen. I. Techniques for freezing bovine spermatozoa in milk diluents. Journal of Dairy Science, 40(12), 1534-1541. doi: 10.3168/jds.S0022-0302(57)94674-X.

O’dell, W. T., Almquist, J. O., \& Marsh, L. A. (1958). Freezing bovine semen. III. Effect of freezing rate on bovine spermatozoa frozen and stored at $-79^{\circ} \mathrm{C}$. Journal of Dairy Science, 41(1), 79-89. doi: 10.3168/jds.S0022-0302(58)90870-1.

Ostashko, F. I., \& Buhrov, O. D. (1966). Pro hlyboke zamorozhuvannia spermy buhaiv-plidnykiv. Visnyk silskohospodarskoi nauky, 4, 86-91 (in Ukrainian).

Ostashko, F. I. (1959). Tryvale zberihannia simia buhaiv pry temperaturi - $183{ }^{\circ} \mathrm{C}$. Sotsialistychne tvarynnytstvo, 11, 36-39 (in Ukrainian).

Ostashko, F. I. (1964). Prichinyi i mehanizm holodovogo udara kletok. Mezhdunarodnyiy hozyaystvenney zhurnal, 3, 68-72 (in Ukrainian).

Ostashko, F. I., \& Lopatko, M. I. (1965). Do pytannia pro zamorozhuvannia spermy plidnykiv. Zb. Rozvedennia i utrymannia silskohospodarskykh tvaryn, 5, 3-8 (in Ukrainian).

Ostashko, F. I., \& Shinkarenko, V. A. (1972). Zamorazhivanie spermyi byikov-proizvoditeley $\mathrm{v}$ oblitsovannyih granulah. Sb. Tezisyi dokladov k nauchno-proizvodstvennoy konferentsii po teorii praktike vosproizvodstva selskohozyaystvennyih zhivotnyih. NII Zhivotnovodstva Lesostepi i Polesya USSR. Harkov, 54-55 (in Russian).

Ostashko, F. I. (1960). Novyiy metod zamorazhivaniya i dlitelnogo hraneniya semeni byikov pri temperature minus 1830S. Zhivotnovodstvo, 1, 79-84 (in Russian).

Ostashko, F. I. (1968). Glubokoe zamorazhivanie i dlitelnoe hranenie spermyi proizvoditeley. K.: Urozhay (in Russian).

Pakenas, P. I. (1963). Metodyi zamorazhivaniya semeni, primenyaemyie $\mathrm{v}$ Litovskim institute zhivotnovodstva $\mathrm{i}$ harakteristika potomstva, poluchennogo ot semeni perevezennogo iz Moskvyi. V kn. Novoe v plemennom dele $\mathrm{i}$ iskusstvennyim osemenenii selskohozyaystvennyih zhivotnyih, 201-207 (in Russian).

Petruk, E. M. (1966). Nekotoryie fiziologicheskie i morfologicheskie pokazateli spermiev pri glubokom zamorazhivanii spermyi byika (Doctoral dissertation, Lvovskiy zooveterinarnyiy institut) (in Russian).

Platov, E. M. (1960). Osmoticheskoe deystvie glitserina na zhivchikov byika. Vestnik selskohozyaystvennoy nauki, 11, 59-63 (in Russian).

Platov, E. M. (1965). Zamorazhivanie semeni barana v laktoz zheltochnoy-etilenglikolevoy srede. Ovtsevodstvo, 9, 11 (in Russian).

Platov, E. M. (1978). Nekotoryie teoreticheskie aspektyi zamorazhivaniya spermyi. Zhivotnovodstvo, 10, 64 (in Russian).

Platov E. M. (1982). Razrabotka i prakticheskoe primenenie tehnologii zamorazhivaniya spermyi baranov. Nauchno-praktich. konf. Po ovtsevodstvu i kozovodstvu: Tez. naukch. saobscheniy, 254-256 (in Russian).

Platov, E. M. (1963). Issledovaniya o deystvii glitserina PRI RAZBAVLENII I zamorazhivanii SEMENI selıskohozyaystvennyih zhivotnyih (Doctoral dissertation, Vsesoyuznaya ordena Lenina akademiya selskohozyaystvennyih nauk imeni VI Lenina; Vsesoyuznyiy ordena Trudovogo Krasnogo Znameni nauchno-issledovatelskiy institut zhivotnovodstva) (in Russian).

Platov, E. M. (1973). Teoreticheskie i prakticheskie osnovyi zamorazhivaniya semeni proizvoditeley selskohozyaystvennyih zhivotnyih. Diss.... d-ra biol. nauk. Dubrovitsyi (in Russian).

Platov, E. M., \& Volkov, A. S. (1979). Effektivnost zamorazhivaniya spermyi baranov. Zhivotnovodstvo, 5, 53-56 (in Russian).

Pokhyl, V., Pokhyl, O., Honchar, A., \& Lesnovska, O. (2011). Miasni porody ovetsu prydniprovi. Tvarynnytstvo Ukrainy, 9, 17-20 (in Ukrainian).

Polge, C., \& Rawson, L. E. A. (1952). Longtery storage of bull semen froen at very low temperatures $-79{ }^{\circ} \mathrm{C}$. Proc 2-nd int. Cong. Anim. Reprod. Artif. Insem, 3, 90-98.

Polge, C. (1953). The preservation of spermatozoa at low temperatures. Mammalian germ cells, 6, 108.

Polge, C., \& Rowson, L. E. A. (1952). Fertilizing capacity of bull spermatozoa after freezing at $-79^{\circ} \mathrm{C}$. Nature, 169(4302), 626-627. doi: 10.1038/169626b0.

Polge, C., \& Rowson, L. E. A. (1952). Results with bull semen stored at-79 C. Vet. Record, 64, 851.

Polge, C., Smith, A. U., \& Parkes, A. S. (1949). Revival of spermatozoa after vitrification and dehydration at low temperatures. Nature, 164(4172), 666. doi: $10.1038 / 164666 \mathrm{a} 0$.

Pursel, V. G., Johnson, L. A., \& Rampacek, G. B. (1972). Acrosome morphology of boar spermatozoa incubated before cold shock. Journal of Animal Science, 34(2), 278-283. doi: 10.2527/jas1972.342278x.

Rhodes, A. (1980). Semen collection and evaluation. Current therapy in theiogenology, 4, 944-947.

Roslanovskiy, K. (1963). Metodyi hraneniya semeni primenyaemyie v Polsche. V. kn.: Novoe v plemennom dele $i$ iskusstvennom osemenenii 
selskohozyaystvennyih zhivotnyih. M. izd.s-h literaturyi, zhurnalov i plakatov, 162-169 (in Russian).

Salamon, S. (1967). Observations on fertility of ram semen frozen by different methods. Australian Journal of Experimental Agriculture, 7(29), 559-561. doi: 10.1071/EA9670559.

Salamon, S. (1968). Deep freezing of ram semen: recovery of spermatozoa after pelleting and comparison with other methods of freezing. Australian journal of biological sciences, 21(2), 351-360. doi: 10.1071/BI9680351.

Salamon, S., \& Visser, D. (1972). Effect of composition of Tris-based diluent and of thawing solution on survival of ram spermatozoa frozen by the pellet method. Australian journal of biological sciences, 25(3), 605-618. doi: 10.1071/BI9720605.

Schmidt, D., Peter, W., Mudra, K., \& Kunze, C. (1974). Untersuchungen zur Gefrierkonservierung von Ebersperma. 3. Prufung der Befruchtungsfahigkeit. Archiv fur Tierzucht.

Semekov, V. G. (1984). Soderzhanie tsiklicheskih nukleotidov (TsAMF i IDGMF) v sperme byikov i hryakov pri kriokonservatsii. Selskohozyaystvennaya biologiya, (2),81-83 (in Russian).

Shaydullin, I. N. (1980). Usovershenstvovanie metoda zamorazhivaniya semeni barana putem primeneniya antioksidantov. Avtoreferat diss. kand. biol. nauk (in Russian).

Shergin, N. P. (1967). Biohimiya spermyi selskohozyaystvennyih zhivotnyih. M.: Kolos (in Russian).

Skornyakov, B. A. (1973). Izuchenie povrezhdenii spermiev byika pri ih nizkotemperaturnoy konservatsii. Avtoreferat kand. diss (in Russian).

Smirnov, I. V. (1951). Sohranenie semeni spermyi selskohozyaystvenyih zhyivotnyih pri temperature $78{ }^{\circ} \mathrm{C}$. Sovetskoe zhyivotnovodstvo, 1, 94-95 (in Russian).

Smirnov, I. V. (1963). Vliyanie glitserina i gipertonicheskih rastvorov na prizhivaemost spermiev byikov-proizvoditeley. Nauchnyie trudyi Kievskoy opyitnoy stantsii zhivotnovodstva, 9, 43-52 (in Russian).

Smirnov, I. V. (1964). Deystvie osmoticheskih faktorov na spermii byikov i hryakov, 85-93 (in Russian).

Smirnov, I. V. (1949). Sohranenie semeni selskohozyaystvennyih zhivotnyih posredstvom glubokogo ohlazhdeniya. Sovetskaya zootehniya, 4, 93-96 (in Russian).

Smirnov, I. V. (1974). K teorii glubokogo ohlazhdeniya spermyi. Zhivotnovodstvo, 11, 65-70 (in Russian).

Sokolovskaya, I. I., Oyvadis, R. N., Abilov, A. I. i dr. (1981). O znachenii okrasom $\mathrm{v}$ otsenke semeni samtsov. Zhivotnovodstvo, 9, 46-47 (in Russian).

Varnavskiy A. N. (1969). Ultrastruktura zhivchikov byika i barana posle glubokogo zamorazhivaniya $\mathrm{v}$ zhidkom azote. Selskohozyaystvennaya biologiya, 3, 469-471 (in Russian).

Varnavskiy, A. N. (1970). Vozmozhnaya prichina snizheniya oplodotvoryayuschey sposobnosti zamorozhennogo semeni. Ovtsevodstvo, 2, 28-29 (in Russian).
Varnavskiy, A. N. Turbin, V. F., \& Osadchuk, V. S. (1972). Podvizhnost i ultrastruktura zhivchikov byika v protsesse tehnologicheskoy obrabotke. Tehnologiya iskusstvennogo osemeneniya i biologiya vosproizvedeniya selskohozyaystvennyih zhivotnyih, 169-175 (in Russian).

Varnivskiy, A. N. (1978). Izuchenie akrasom spermatozoidov baranov $\mathrm{s}$ pomoschyu fazokontrastnoy mikroskopii. Dokladyi VASHNIL, 8, 33-34 (in Russian)

Visser, D., \& Salamon, S. (1974). Fertility following inseminations with frozen-thawed reconcentrated and unconcentrated ram semen. Australian journal of biological sciences, 27(4), 423-426. doi: 10.1071/BI9740423.

Volkov, A. S. (1971). Izuchenie oplodotvoryaemoy ovets pri osemenenii zamorozhennyim semenem barana. Avtoreferat kand. diss. Dubrovitsyi (in Russian).

Volkov, A. S. (1974). Vliyanie chisla aktivnyih zhivchikov $\mathrm{V}$ ottayannom semeni na oplodotvoryaemost ovets. Zhivotnovodstvo, 10, 69-71 (in Russian).

Voronenko, V., Iovenko, V., \& Zharuk, P. (2009). Henetychni resursy ovets Ukrainy ta umovy yikh podalshoho rozvytku. Naukovyi visnyk Natsionalnoho universytetu bioresursiv i pryrodokorystuvannia Ukrainy, 287-296 (in Ukrainian).

Watson, P. (1975). Use of a Giemsa stain to defect changes in aerosomes of frozen ram spermatozoa. Veter. Res., 97(1), 12-15. doi: 10.1136/vr.97.1.12.

Watson, P. F. (1981). The effect cold shock on sperm cell membrane. Effect of Low temperatures on the biological membranes, 198-218.

Watson, P. F. (1975). Use of a Giemsa stain to detect changes in acrosomes of frozen ram spermatozoa. The Veterinary Record, 97(1), 12. doi: 10.1136/vr.97.1.12.

White, I. D., Blackshaw, A. W., \& Emmens, C. W. (1954). Metabolic and motility studies relating to the low temperature storage of ram and bull spermatozoa. Australian Veterinary Journal, 30(4), 85-94. doi: 10.1111/j.1751-0813.1954.tb08161.x.

Wiggin, H. B., \& Almquist, J. O. (1975). Effect of glycerol equilibration time and thawing rate upon acrosomal maintenance and motility of bull spermatozoa frozen in plastic straws. Journal of animal science, 40(2), 302-305. doi: $10.2527 /$ jas $1975.402302 x$.

Wilmut, I., \& Polge, C. (1977). The low temperature preservation of boar spermatozoa. 1. The motility and morphology of boar spermatozoa frozen and thawed in the presence of permeating protective agents. Cryobiology, 14(4), 471-478. doi: 10.1016/00112240(77)90009-8.

Yatsun, A. S., \& Ilinskaya, T. P. (1969). O pronitsaemosti glitserina cherez obolochku spermiev. V sb. Aktualnyie voprosyi povyisheniya produktivnosti selskohozyaystvennyih zhivotnyih. Minsk, Urozhay, 75-78 (in Russian).

Yuschenko, N. P., Semakov, V. G., \& Levin, K. A. (1963). Zamorazhivanie spermyi byikov $\mathrm{V}$ granulah bez primeneniya suhogo lda. Molochnoe i myasnoe skotovodstvo, 5, 36-37 (in Russian). 
Zheltobryuh, N. A., \& Ivahnenko, V. K. (1977). Primeneniya saharno-zheltochnyih sred dlya zamorazhivaniya spermyi barana. Tr. VNIIOK, 39(1),111-118 (in Russian).

Zheltobryuh, N. A., \& Ivahnenko, V. K. (1977). Sovershenstvovanie tehnologii zamorazhivaniya i ottaivaniya spermyi barana. Mat. nauchno-proizv, 27 28 (in Russian).

Zhiltsov, N. Z. (1970). Kontsentratsiya kisloroda v kanale epididimisa krolika. Dokladyi VASHNIL, 5, 34-35 (in Russian).

Zhiltsov, N. Z., Golub, V. S., Varnavskaya, V. A. i dr. (1974). O vozmozhnosti primeneniya prostaglandinov dlya povyisheniya effektivnosti osemeneniya ovets. Zhivotnovodstvo, 8, 67-70 (in Russian).
Zhiltsov, N. Z. (1999). Novoe v biologii vosproizvedeniya selskohozyaystvennyih zhivotnyih. Zootehniya, 11, 31 (in Russian).

Zvereva, A. P. (1976). Sovershenstvovanie tehnologii zamorazhivaniya spermyi byikov-proizvoditeley i ispyitanie novyih krioprotektorov. Avtoreferat kand. dis (in Russian).

Zvereva, A. P. (1977). Vliyanie protsessov adaptatsii i ekvilibratsii na biologicheskie svoystva spermiev byikov pri zamorazhivanii. Fiziologiya vosproizvodstva selskohozyaystvennyih zhivotnyih, 229-232 (in Russian).

Zvereva, G. V., \& Chernomaz, L. A. (1977). Nekotoryie voprosyi morfologii spermiev byika. $\mathrm{V}$ kn. Novoe $\mathrm{v}$ plemennom dele $\mathrm{i}$ iskusstvennom osemenenii selskohozyaystvennyih zhivotnyih, 378-388 (in Russian). 